\title{
Wind-induced upwelling in the Kerguelen Plateau region
}

\author{
S. T. Gille ${ }^{1}$, M. M. Carranza ${ }^{1}$, R. Cambra ${ }^{2, *}$, and R. Morrow ${ }^{2}$ \\ ${ }^{1}$ Scripps Institution of Oceanography, University of California, San Diego, USA \\ ${ }^{2}$ Laboratoire d'Etudes en Géophysique et Océanographie Spatiale, Observatoire Midi-Pyrénées, 31400 Toulouse, France \\ *now at: Laboratoire Atmosphères, Milieux, Observations Spatiales, Institute Pierre-Simon Laplace, Paris, France
}

Correspondence to: S. T. Gille (sgille@ucsd.edu)

Received: 14 May 2014 - Published in Biogeosciences Discuss.: 5 June 2014

Revised: 11 October 2014 - Accepted: 20 October 2014 - Published: 26 November 2014

\begin{abstract}
In contrast to most of the Southern Ocean, the Kerguelen Plateau supports an unusually strong spring chlorophyll (Chl $a$ ) bloom, likely because the euphotic zone in the region is supplied with higher iron concentrations. This study uses satellite wind, sea surface temperature (SST), and ocean color data to explore the impact of wind-driven processes on upwelling of cold (presumably iron-rich) water to the euphotic zone. Results show that, in the Kerguelen region, cold SSTs correlate with high wind speeds, implying that windmixing leads to enhanced vertical mixing. Cold SSTs also correlate with negative wind-stress curl, implying that Ekman pumping can further enhance upwelling. In the moderate to high eddy kinetic energy (EKE) regions surrounding Kerguelen, we find evidence of coupling between winds and SST gradients associated with mesoscale eddies, which can locally modulate the wind-stress curl. This coupling introduces persistent wind-stress curl patterns and Ekman pumping around these long-lived eddies, which may modulate the evolution of Chl $a$ in the downstream plume far offshore. Close to the plateau, this eddy coupling breaks down. Kerguelen has a significant wind shadow on its downwind side, which changes position depending on the prevailing wind and which generates a wind-stress curl dipole that shifts location depending on wind direction. This leads to locally enhanced Ekman pumping for a few hundred kilometers downstream from the Kerguelen Plateau; Chl $a$ values tend to be more elevated in places where wind-stress curl induces Ekman upwelling than in locations of downwelling, although the estimated upwelling rates are too small for this relationship to derive from direct effects on upward iron supply, and thus other processes, which remain to be determined, must also be involved in the establishment of these correlations.
\end{abstract}

During the October and November (2011) KErguelen Ocean and Plateau compared Study (KEOPS-2) field program, wind conditions were fairly typical for the region, with enhanced Ekman upwelling expected to the north of the Kerguelen Islands.

\section{Introduction}

The Southern Ocean is characterized as a region of high macronutrients but low chlorophyll (HNLC), where low concentrations of dissolved iron inhibit growth of phytoplankton, despite the presence of ample quantities of macronutrients (Martin et al., 1990; Boyd, 2002; de Baar et al., 2005; Hopkinson et al., 2007). Exceptions to the HNLC regime occur in a few limited areas, primarily near the Antarctic continental shelf (e.g., Moore and Abbott, 2000; Holm-Hansen et al., 2004; Kahru et al., 2007; Charette et al., 2007; Arrigo et al., 2008; Dulaiova et al., 2009; Frants et al., 2013) or near specific islands (e.g., Blain et al., 2007; Pollard et al., 2007; Planquette et al., 2007; Venables et al., 2007; Korb et al., 2008), where iron can be supplied to surface waters from lithogenic sources or from ocean sediments (e.g., Measures et al., 2012). The plateau surrounding the Kerguelen Islands supports a particularly strong bloom, which has been the target of two KErguelen Ocean and Plateau compared Study (KEOPS) field campaigns (e.g., Blain et al., 2007, 2008; Park et al., 2008a, b, 2014b; van Beek et al., 2008; Sanial et al., 2014; Zhou et al., 2014; van der Merwe et al., 2014, and other papers in this volume). KEOPS results show evidence that, in comparatively shallow water over the Kerguelen Plateau, bottom waters are enriched in dissolved iron 
and then advected horizontally by the Polar Front (Blain et al., 2008; van Beek et al., 2008; Sanial et al., 2014). Enhanced vertical mixing in the upper ocean may help to bring dissolved iron upwards into the euphotic zone (Park et al., 2008a).

In most of the Southern Ocean, wind forcing is thought to influence seasonal and interannual variations in biological productivity through several competing mechanisms. Strong winds can deepen the mixed layer, bringing up to the euphotic zone cold water that is rich in iron and macronutrients, thus enhancing phytoplankton growth. In some places, and particularly in low-stratification environments, such as those that commonly occur in the Southern Ocean, strong winds can also deepen the mixed layer enough to mix phytoplankton over large vertical distances, thus reducing average light levels and possibly limiting phytoplankton growth (e.g., Kahru et al., 2010; Fauchereau et al., 2011). Typically along the primary axis of the Antarctic Circumpolar Current (ACC), around $50^{\circ} \mathrm{S}$ in the Kerguelen region, mean wind stress is a maximum, and wind-stress curl is zero. Depending on the sign of the wind-stress curl, this may play a further role in biological productivity: south of the zero wind-stress curl line, Ekman pumping drives upwelling, which can bring iron and macronutrients upward from below the mixed layer, while, to the north, Ekman pumping results in downwelling (Carranza and Gille, 2014). While wind mixing and Ekman pumping provide a basic framework for evaluating largescale processes, at any given location, local effects can significantly modify large-scale wind processes. At eddy-length scales, sea surface temperature (SST) anomalies can modify surface winds, which tend to accelerate over warm water and slow over cool water, resulting in local modifications to the wind-stress curl and divergence (e.g., O'Neill et al., 2003, 2005 ) and correspondingly to the local Ekman pumping velocity. In addition, eddies themselves influence local chlorophyll $a(\mathrm{Chl} a$ ) concentrations, and this may be associated both with horizontal advection induced by the eddies (e.g., Chelton et al., 2011), with eddy influences on upper ocean stratification (e.g., Mahadevan et al., 2012), or from strong vertical velocities induced within the filaments surrounding the eddies (e.g., Lévy et al., 2012).

While wind-driven upwelling appears to help determine variability in phytoplankton growth in regions of the Southern Ocean that are far from land (e.g., Kahru et al., 2010; Fauchereau et al., 2011; Carranza and Gille, 2014), the role of wind is less clear in areas near islands where phytoplankton blooms are stronger and more persistent, and where a broader range of processes might be expected to control iron availability. These processes include oceanic transport processes, which might vary the sediment content of water advected away from the island shelf (e.g., Park et al., 2008b; van Beek et al., 2008; van der Merwe et al., 2014), and processes that influence lithogenic sources of iron from the Kerguelen Islands (e.g., Bucciarelli et al., 2001; Chever et al., 2010; Sanial et al., 2014), as well as local orographic influ- ences on winds. For example, Kerguelen is $1850 \mathrm{~m}$ tall and produces a substantial wind shadow, which, in turn, modifies the wind-stress curl (Chelton et al., 2004). The present study was thus carried out as a complement to the second KEOPS field campaign (KEOPS-2), with the aim to assess the extent to which wind-driven upwelling mechanisms might contribute to the iron availability and biological productivity in the region around Kerguelen.

In this study, we focus on two key issues. First, for the region around Kerguelen, we evaluate the extent to which the wind stress and wind-stress curl driven mechanisms control SST (and, by extension, iron, macronutrients, and Chl $a$, as shown in Fig. 1). This is examined both on the regional scale and also for wind-eddy coupling associated with mesoscale motions. As part of this analysis, we specifically consider the role that the Kerguelen wind shadow could play in modifying wind-driven upwelling. Second, we evaluate whether winddriven processes play a significant role in the region around Kerguelen, where a large bloom is present. SST will serve as a proxy for iron and macronutrients for much of this analysis. Chl $a$ is more difficult to interpret than SST, because satellite-derived Chl $a$ estimates are only available in cloudfree conditions, which are comparatively rare in the Southern Ocean, and because phytoplankton require time to grow after they are first exposed to optimal iron, macronutrient, and light levels, and thus Chl $a$ concentrations can lag physical parameters by an increment of time that has not been determined precisely.

SST and Chl $a$ can also differ in fundamental ways: SST anomalies can influence wind, inducing a coupled air-sea interaction, whereas $\mathrm{Chl} a$ concentrations do not influence wind. Section 2 discusses the range of satellite data and reanalysis products that we consider for this analysis; Sect. 3 briefly summarizes the computational methodology; Sect. 4 presents the results; Sect. 5 provides a summary and conclusions.

\section{Data}

Vector wind data were derived from scatterometer measurements obtained by the Quick Scatterometer (QuikSCAT) satellite, which operated from June 1999 through November 2009 (Freilich et al., 1994). We made use of daily and weekly averages of the QuikSCAT level 4 gridded mean wind fields produced by L'Institut Français de Recherche pour l'Exploitation de la Mer's Center for Satellite Exploitation and Research (Ifremer/CERSAT). Data are released on a $0.5^{\circ}$ regular grid (cersat.ifremer.fr). Since QuikSCAT failed in 2009 for the time period corresponding to the KEOPS-2 field program, we use cross-calibrated multi-platform (CCMP) winds (Atlas et al., 2008, 2009), which our tests show to be effective at capturing wind variability on time scales as short as the diurnal cycle (Carranza and Gille, 2014). 

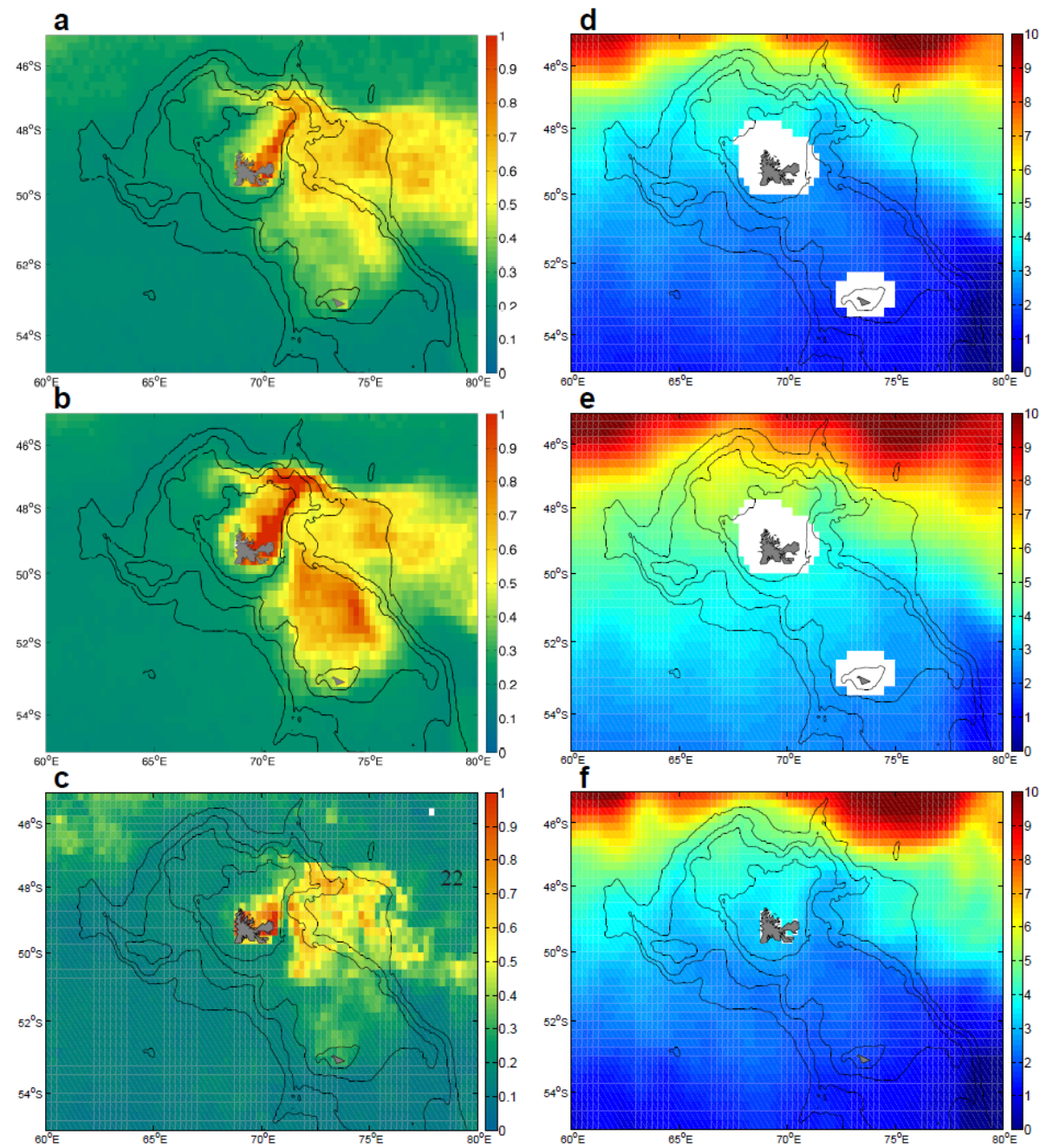

Figure 1. (a-c) Mean Chl $a$ (in $\mathrm{mg} \mathrm{m}^{-3}$ ) for the Kerguelen region. (a) Climatological mean for the spring bloom, averaged over October, November, and December, 2000-2010. (b) Climatological mean for the summer bloom averaged over December, January, and February, 2000-2010. (c) Mean for the KEOPS-2 research cruise, averaged over October and November 2011. Because Chl $a$ is lognormally distributed, here the mean is computed as $\exp (\operatorname{mean}(\log (\mathrm{Chl} a)))$, where $\log$ refers to the natural $\log$ and exp refers to an exponential. (d-f) Mean SST (in ${ }^{\circ} \mathrm{C}$ ) for the Kerguelen region. (d) For October, November, and December, as in (a); (e) for December, January, and February, as in (b); (f) for October and November 2011, as in (c). In this figure and subsequent figures, bathymetry is contoured at depths of 3000, 2000, 1000, and $200 \mathrm{~m}$.

SST data were obtained from the Advanced Microwave Scanning Radiometer for the Earth Observing System (AMSR-E), which operated from June 2002 through early October 2011 (Chelton and Wentz, 2005). We use version 3 of the objectively interpolated fields distributed by remote sensing systems (RSSs). The SST data fields formally merge measurements from three microwave sensors - TMI, AMSR$\mathrm{E}$, and WindSat -, but we consider a latitude range and time period when the fields should be determined only by AMSRE. The data are daily averages on a $0.25^{\circ}$ grid. Microwave SST data have the advantage of being available in almost all non-precipitating weather conditions, in contrast to infrared SST data, which offer higher spatial resolution but do not return data in cloudy conditions. Clouds are preva- lent about $70 \%$ of the time in the mid-latitude regions, such as the Southern Ocean (Chelton and Wentz, 2005). For this study, data were analyzed over a 7-year time period from 1 November 2002 through 31 October 2009, chosen to represent an integer number of years and to have both QuikSCAT winds and AMSR-E SSTs available. From this time period, we have omitted 5 isolated days for which wind data were missing from the CERSAT records. Unless otherwise stated, all analyses in this paper were carried out for the full time interval. Figure 1d shows the climatological mean SST for spring, and Fig. 1e shows summer SST. For October and November in 2011, when the KEOPS-2 field program took place, SSTs from WindSat are used (Fig. 1f). 
Sea surface geostrophic velocity anomalies (relative to a temporal mean from 1992-1999) were produced by the SSALTO/DUACS project, based on a multi-satellite altimeter product (Le Traon et al., 1998; Ducet et al., 2000; Dibarboure et al., 2011). These data, which are distributed by AVISO, are released at weekly intervals, and each map uses roughly a 2-week window of satellite observations, mapped on a regular Mercator grid with a grid spacing of $0.33^{\circ}$ longitude by roughly $0.2^{\circ}$ latitude. Eddy kinetic energy (EKE) was computed by first removing the mean for the analysis time period in order to obtain velocity anomalies $u^{\prime}$ and $v^{\prime}$, and then computing $\mathrm{EKE}=\left(u^{\prime 2}+v^{\prime 2}\right) / 2$.

We use net surface heat fluxes from NCEP Climate Forecast System Reanalysis (NCEP/CFSR, Saha et al., 2010). This is a high resolution coupled global reanalysis that incorporates satellite measurements. Net surface-heat-flux accuracy increases over time in NCEP/CFSR and shows smaller biases than the NCEP/NCAR reanalysis (Saha et al., 2010; Xue et al., 2010). They are available at $1 \mathrm{hr}$ and $0.5^{\circ} \times 0.5^{\circ}$, and we spatially interpolated and averaged the heat fluxes in time to match the resolution of satellite fields.

Finally, we considered ocean color data as a proxy for $\mathrm{Chl} a$ concentration at the ocean surface. Figure 1a shows climatological spring, and Fig. 1b shows summer Chl $a$ distributions for the Kerguelen region. We use a weight-averaged merged product that is determined using the bio-optical model described by Maritorena and Siegel (2005). Data are distributed by the GlobColour project from the European Space Agency (http://hermes.acri.fr). The merged product is available on a $0.25^{\circ} \times 0.25^{\circ}$ grid at daily and weekly (i.e., 8 -day) time intervals, and it minimizes data gaps due to persistent cloud cover and low sun angles. These Chl $a$ distributions illustrate the persistent high productivity that occurs on the Kerguelen Plateau and just to the east of it. Distributions during the KEOPS-2 cruise time period (Fig. 1c) are fairly typical of spring Chl $a$ blooms, shown in Fig. 1a.

\section{Methodology}

In this study, we examine both the large-scale patterns of correlation between daily wind forcing and SST, and also the longer-time-scale local, mesoscale modifications to these patterns, specifically focusing on the broad region surrounding the Kerguelen Plateau. Several analyses have demonstrated a clear relationship between mesoscale SST features and surface winds (e.g., O'Neill et al., 2003, 2005). For example, O'Neill et al. (2003) showed that, throughout the Southern Ocean, large SST gradients associated with narrow frontal features (with spatial scales of $10-100 \mathrm{~km}$ ) have a significant impact on the overlying winds. The atmospheric boundary layer is less stable over warm water than cold water, and this induces greater vertical mixing of momentum and correspondingly higher surface winds over warm water than over cold water. O'Neill et al. (2003) showed that
SST gradients thus induce cross-isotherm gradients in wind speed. For wind directed along isotherms, this leads to a nonzero wind-stress curl, which, through Ekman pumping, can drive localized vertical velocities $(w=\operatorname{curl}(\tau) / \rho f)$, where $\tau$ is wind-stress, $\rho$ is density, and $f$ is the Coriolis parameter. In the Southern Hemisphere, negative wind-stress curl induces upward Ekman pumping velocities (i.e., $w>0$ ). For winds directed across isotherms, SST-induced modifications of the atmospheric boundary layer can induce a non-zero divergence of the wind stress. We hypothesize that, far from Kerguelen, mesoscale SST should influence wind-stress curl or divergence, but, close to Kerguelen, this mechanism might break down.

Our approach follows that of O'Neill et al. (2003, 2005). In order to minimize the impact of synoptic-scale storms, data were averaged over 3-month periods for some aspects of this analysis; 3 months correspond to the typical decorrelation time scales for oceanic eddies (Phillips and Rintoul, 2000). Wind speed, wind-stress curl, and SST all have largescale meridional gradients, with significant gradients across the ACC fronts. For the 3-month averaged data, a spatial filter was applied to remove scales larger than $10^{\circ}$ latitude by $30^{\circ}$ longitude from the data, in order to retain only mesoscale disturbances.

The variables analyzed in this study are interdependent. For example, SST and wind are both influenced by air-sea buoyancy fluxes because of processes occurring in the atmospheric boundary layer that are not expected to influence iron or nutrient upwelling. Thus, for some components of this study, we use partial correlations, which provide a formal mechanism to compute a correlation coefficient while controlling for the influence of additional variables (e.g., Prokhorov, 2001; Baba et al., 2004). In essence, to compute the partial correlation of wind speed $(W)$ and SST, controlled for air-sea flux $\left(Q_{\text {net }}\right)$, we first remove the component of the $W$-SST correlation that could be explained, because both $W$ and SST are individually correlated with $Q_{\text {net }}$. Here, partial correlations are applied to the unfiltered data.

\section{Results}

\subsection{Assessing SST-wind relationships}

We correlate wind speed and SST (Fig. 2a), using the method of partial correlations to control for the impact of $Q_{\text {net }}$ (Baba et al., 2004). Through most of the Southern Ocean, in yearround data, high wind speeds are associated with cold SSTs, implying that wind-induced mixing deepens the mixed layer and brings cold water, iron, and macronutrients to the surface (Kahru et al., 2010), and during spring and summer this can promote phytoplankton growth (Carranza and Gille, 2014). In winter and early spring, when stratification is low, high winds can deepen the mixed layer and move phytoplankton out of the euphotic zone, resulting in low Chl $a$ (Kahru et al., 


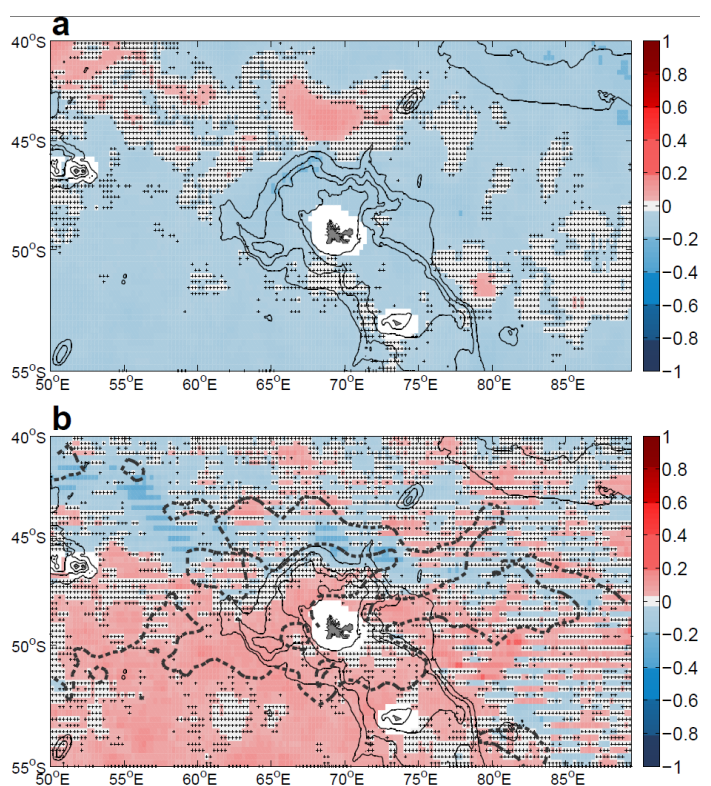

Figure 2. Partial correlation coefficients for unfiltered daily anomalies of (a) wind speed vs. SST and (b) wind-stress curl vs. SST, in both cases controlled for NCEP/CFSR surface heat fluxes. Partial correlations are computed for the spring and summer growing season only, from September to February. In (a) blues indicate that positive wind anomalies are associated with cold SSTs, and in (b) reds in the region adjacent to Kerguelen indicate that negative wind-stress curl is linked to cold SSTs. Pixels are cross-hatched where the correlation coefficient is not statistically significant at the $95 \%$. Black dashed line indicates the climatological mean zerowind-stress curl line; negative wind-stress curl occurs south of the zero-wind-stress curl line (and within closed contours to the north) and corresponds to upward vertical Ekman pumping.

2010), but the focus of this study is on spring and summer. As hypothesized, wind speed and SST are negatively correlated (blue) almost everywhere, except in some locations to the north of Kerguelen. Positive correlations (red) fall along the Subantarctic Front and Polar Front of the ACC, which represent the primary axes of the current. Here, changes in SST can feed back on the winds. This positive correlation, associated with the mesoscale, vanishes when we high-pass filter the data to consider synoptic storm effects (Carranza and Gille, 2014), implying that large-scale storms suppress eddy feedback effects. Due east of Kerguelen, in the Kerguelen wind shadow region, high winds correlate with cold SSTs (Fig. 2a), but not necessarily with high Chl $a$ (not shown), implying that iron and macronutrient sources are somewhat different near the Kerguelen Plateau than they are in the open ocean.

Wind-stress curl correlations with SST (Fig. 2b) differ on either side of the zero wind-stress curl line. To the south of the zero wind-stress curl line, where negative windstress curl prevails (implying mean upward Ekman pumping), wind-stress curl is positively correlated with SST (red in Fig. 2b), implying that, in most regions typical of Kerguelen, positive Ekman pumping (upwelling) events bring colder (and perhaps more iron-rich) waters to the ocean surface. To the north of the zero wind-stress curl line, negative correlations suggest that downwelling is associated with warm SST, but, along the axis of the ACC, Fig. 2b shows patches of positive correlation, suggesting that SST impacts on wind may influence the correlation (even in this case, in which partial correlations have been used to control for $Q_{\text {net }}$.)

Next, we filter to consider the impact of mesoscale eddies (Fig. 3) following the approach of O'Neill et al. (2003). As an example for the time period corresponding to the KEOPS1 field work from December 2004 to February 2005, Fig. 3a shows the wind-stress curl and Fig. 3c shows the associated crosswind component of the SST gradient. Fig. $3 b$ shows the wind-stress divergence, and Fig. 3d shows the down-wind component of the SST gradient. The wind-stress curl has elongated zonal structures, aligned along the main Southern Ocean fronts, which are reflected in the large spatial patterns of Fig. 3c. Meanwhile, the wind-stress divergence has isolated anomalies, generated around the large stationary meanders of the Southern Ocean fronts, which are reflected in the smaller-scale structure of the temperature gradient in Fig. 3d. Areas in which the two components of the SST gradient are strongest, between $1.5 \times 10^{-2}$ and $4 \times 10^{-2}{ }^{\circ} \mathrm{C} \mathrm{m}^{-1}$, correspond to the region of strong SST gradients and high EKE, calculated from geostrophic velocities from satellite altimetry, as shown in Fig. 3e. This occurs along the axis of the ACC, north and west of Kerguelen.

In general, the coupling between wind-stress curl and SST gradient is clearest in regions in which EKE is greatest, and is not as strong in regions of less intense EKE, close to Kerguelen. Figure $3 \mathrm{f}$ shows the zero-lag correlation coefficient between wind-stress curl and the crosswind component of the SST gradient for the time period from 1 November 2002 through 31 October 2009. For Fig. 3f, 3-month time periods are used, and consecutive time windows overlap by 3 months, resulting in a total of 423 -month periods. Because of the overlap, we assume the number of statistically independent samples to be two-thirds of 42 ; the $95 \%$ significance level is 0.37 , and correlation coefficients that are less than 0.37 appear white or pale gray. The correlation coefficient is positive (red) and statistically significant for most of the region surrounding Kerguelen, in agreement with the relationships between wind-stress curl and SST, identified by O'Neill et al. (2003, 2005). Areas with high EKE in Fig. 3e generally have statistically significant positive correlations in Fig. 3f, implying that the wind-stress curl-SST relationship is present within the ACC, where EKE is moderate to high.

Figure $3 \mathrm{f}$ also indicates that this mesoscale wind coupling occurs in waters deeper than $2000 \mathrm{~m}$, including in the deeper basin to the east of Kerguelen, within the extended Chl $a$ bloom, shown in Fig. 1a-c, where KEOPS-2 observations were made. In this deep basin, the wind-induced coupling drives persistent zones of Ekman-driven upwelling 

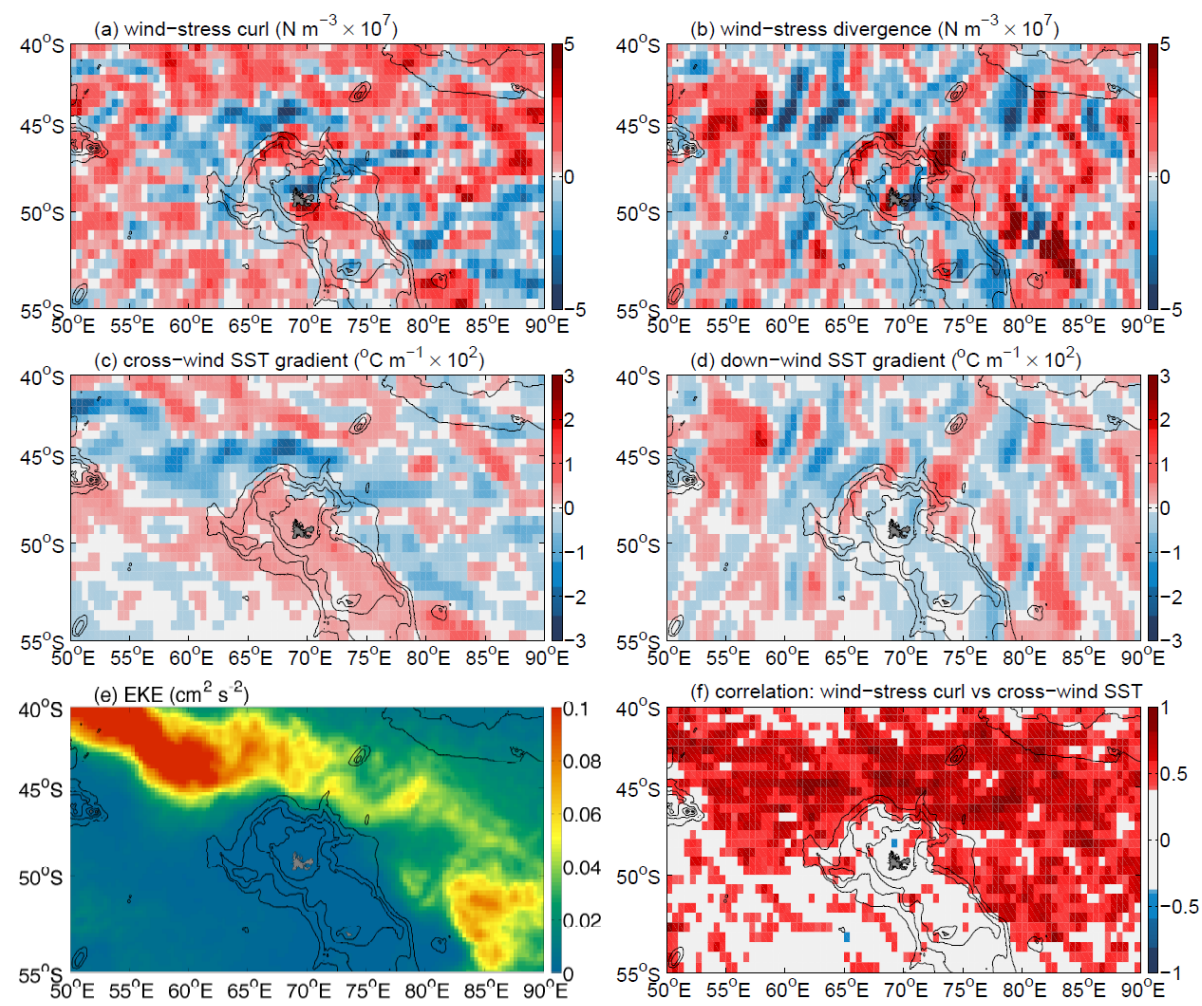

Figure 3. (a) Wind-stress curl (in $\mathrm{N} \mathrm{m}^{-3} \times 10^{7}$ ) for December 2004 to February 2005, spatially filtered to remove large-scale signal, as discussed in the text. (b) Wind-stress divergence (in $\mathrm{N} \mathrm{m}^{-3} \times 10^{7}$ ) for the same time period, also spatially filtered. (c) Crosswind components of the SST gradient (in ${ }^{\circ} \mathrm{C} \mathrm{m}^{-1} \times 10^{2}$ ) derived from QuikSCAT wind data and AMSR-E microwave SST. SST gradients are filtered spatially using a $10^{\circ} \times 30^{\circ}$ window, averaged over the period from December 2004 to February 2005. Isobaths are plotted at 200 and at $1000 \mathrm{~m}$ intervals. (d) Downwind component of SST gradient (in ${ }^{\circ} \mathrm{C} \mathrm{m}^{-1} \times 10^{2}$ ), computed the same way as in panel (c). (e) Eddy kinetic energy derived from satellite altimetry, showing high eddy kinetic energy to the north of Kerguelen, along the core of the Antarctic circumpolar current. (f) Correlation between wind-stress curl and the crosswind component of the SST gradient, computed using 42 3-month samples, with consecutive samples overlapping by 1 month. White areas are not statistically significant at the $95 \%$ level.

and downwelling that are generated around the long-lived ( $\mathrm{O}(3$ months $))$ mesoscale eddies and meanders. As Gaube et al. (2013) demonstrated in the eastern Indian Ocean, eddyscale processes can modulate $\mathrm{Chl} a$ in a manner consistent with eddy-induced Ekman upwelling; assuming similar processes occur in the KEOPS-2 region, they could be responsible for exchanging macronutrients, iron, or even Chl $a$ between subsurface and surface layers.

Perhaps more surprising is the fact that the coupling between wind-stress curl and the SST gradient is low on the Kerguelen Plateau and due east of Kerguelen (around $48^{\circ} \mathrm{S}$, $75^{\circ} \mathrm{E}$ ), where SST gradients are nonetheless strong (Fig. 3c), and where we would normally expect to find high correlations. In these regions, we hypothesize that the orography of Kerguelen itself may influence the wind-stress curl, and this topic will be addressed in the next section.

\subsection{Impact of the Kerguelen wind-shadow}

The $1850 \mathrm{~m}$ maximum elevation of the Kerguelen Islands is sufficient to generate a substantial wind shadow (Chelton et al., 2004). Downstream from Kerguelen, the wind shadow induces positive wind-stress curl (downwelling) to the south of the wind shadow and negative wind-stress curl (upwelling) to the north. Chelton et al. (2004) showed the structure of the wind shadow in the case of zonal winds. In reality, in the Kerguelen region, wind direction is not strictly zonal, as illustrated in Fig. 4, which shows a probability density function of daily wind-stress directions observed from the analysis period at $49.25^{\circ} \mathrm{S}, 71.25^{\circ} \mathrm{E}$. (For these calculations, the unfiltered daily Ifremer/CERSAT stress fields were used.) Percentages in Fig. 4 indicate the fraction of the total days on which wind was in the most frequent $30^{\circ}$ sectors, with uncertainties computed as two standard deviations of 100 realizations of a bootstrap procedure with resampling. For example, $25 \pm 2 \%$ of the time, winds were within $\pm 15^{\circ}$ of due east.

In order to evaluate the impact of the wind shadow in the region immediately surrounding Kerguelen, we sorted wind-stress curl data into bins on the basis of the prevailing wind direction to produce conditionally sampled mean windstress curl estimates, as shown in Fig. 5. The four panels of Fig. 5 correspond to $30^{\circ}$ wind directional sectors, and black 


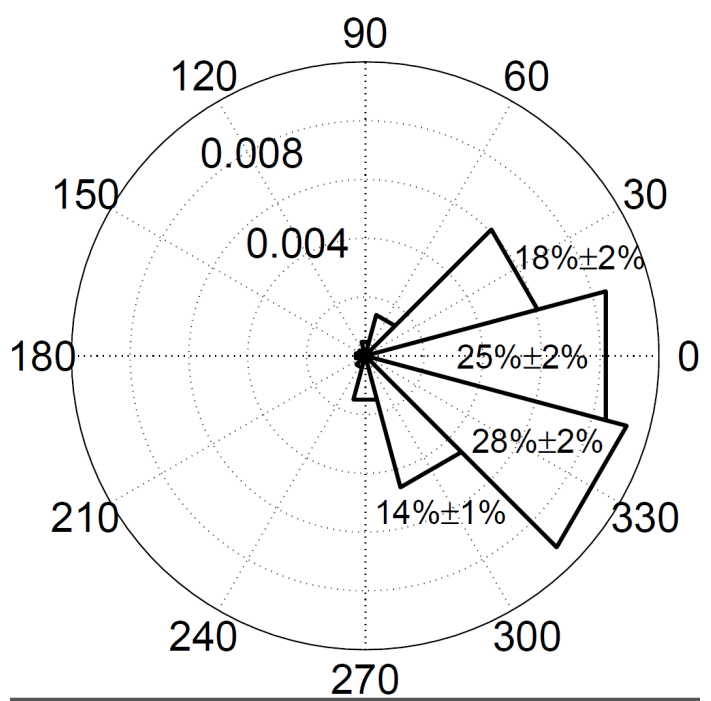

Figure 4. Probability density function of wind direction at $49.25^{\circ} \mathrm{S}$, $71.25^{\circ} \mathrm{E}$, just to the east of Kerguelen. The pdf is represented as a rose histogram, appropriately normalized so that the representation is not dependent on bin width or sample size. A total of 2522 daily wind observations are used. Also indicated are the percentages of days on which winds fall into each of the four most common directional bins, with $2 \sigma$ uncertainties determined from a 100-realization bootstrap with resampling.

arrows show the prevailing wind direction for each panel. Regardless of the prevailing wind direction, a wind-stress curl dipole is established. For roughly westerly winds, upwellingfavorable negative wind-stress curl develops to the north of the wind shadow region, and positive wind-stress curl to the south. This wind-shadow induced structure typically extends more than $200 \mathrm{~km}$ offshore from Kerguelen, extending across the Kerguelen Plateau. More than $50 \%$ of the time, winds are from the west or west-northwest (Fig. 4), giving rise to the distinct pattern of negative wind-stress curl to the northeast of the Kerguelen Islands, and positive wind-stress curl to the southeast, discussed by Chelton et al. (2004). This pattern also occurs in the period from December 2004 to February 2005, shown in Fig. 3a.

Wind direction can shift rapidly, and many of the regions around Kerguelen are likely to experience both positive and negative wind-stress curl associated with the Kerguelen wind shadow. For example, in Fig. 5, the pixels at $49^{\circ} \mathrm{S}, 71^{\circ} \mathrm{E}$, just to the east of Kerguelen, can have a positive or negative wind-stress curl, depending on the prevailing wind direction.

Negative wind-stress curl is predicted to induce upward vertical Ekman pumping velocities. While numerous factors influence Chl $a$ in addition to wind forcing, Chl $a$ anomalies, sorted by prevailing wind direction (Fig. 6), indicate higher Chl $a$ in the upwelling-favorable areas on the northern sides of the wind-stress curl dipoles, shown in Fig. 5. To the northeast of Kerguelen, a shallow plateau extends along $48^{\circ} \mathrm{S}$ in a region in which the eddy coupling is weak (Fig. 3f) but the Ekman pumping from the predominant winds is negative, leading to persistent upwelling (Fig. 5c) and consistently high Chl $a$ blooms (Figs. 1 and 6c). Southeast of Kerguelen, springtime Chl $a$ is, on average, lower (Fig. 1a,c), coinciding with downward Ekman pumping with a high variance in Fig. 5b-c. Thus, this is consistent with the hypothesis that orographic wind-stress curl effects can amplify upwelling (of iron, macronutrients, and also Chl $a$ itself), particularly in the upwelling-favorable portion of the wind-stress curl dipole.

KEOPS-1 observations indicate the presence of a subsurface iron maximum at the depth of the shelf around $500 \mathrm{~m}$ (Blain et al., 2008). We suggest that the persistent windinduced upwelling may carry sub-surface iron-rich water or may help retain water that is high in Chl $a$ at the ocean surface, particularly in the region of the shallower plateau to the northeast of Kerguelen. Lateral advection may then carry this iron-rich (and possibly Chl $a$-rich) surface layer into the deeper regions downstream, along the northern flank of the Polar Front, or within the surface Ekman layer. During KEOPS-2, no vertical iron profiles have been reported from the shallow plateau northeast of the Kerguelen Islands. However, KEOPS-2 iron profiles from the deep basin east of Kerguelen and south of the Polar Front showed a different pattern, with iron maxima at the surface and at a depth of about $500 \mathrm{~m}$, with a minimum in the winter water layer around a depth of 100 to $200 \mathrm{~m}$ (van der Merwe et al., 2014). Our results indicate that, during the KEOPS- 2 period, regional Ekman pumping was downwelling-favorable over this deep basin (Fig. 7), and only the wind coupling over mesoscale eddies or meanders would have been expected to modulate upwelling processes. In this deep basin, numerous other processes may also influence biological productivity on and downstream from the Kerguelen Plateau, including horizontal circulation coming from the sediment-rich Kerguelen Plateau and eddy circulation associated with flow over and around the Plateau (see Park et al., 2014a; Zhou et al., 2014).

While the bulk of this analysis was carried out for the 2002-2009 time period, when QuikSCAT winds and microwave SST were both available, we also evaluated the KEOPS-2 time period (see Fig. 1c and f) to check whether it was distinctive in any way from the main analysis period. In general, October and November wind conditions during the 2011 KEOPS- 2 expedition were typical for the region. Details of the winds and Chl $a$ differ from year to year, so that a formal statistical test, such as the Kolmogorov-Smirnov test, indicates that neither wind speed nor $\mathrm{Chl} a$ for any given year appears to be drawn from the same distribution as the climatology from all years combined together. Less stringent tests indicate that the October and November 2011 mean and standard deviation (for wind speed or for Chl $a$ ) are not statistically different from the means and standard deviations of individual years between October and November in 2003 through 2009. A rose histogram for wind direction for October and November, 2011 (Fig. 7a), indicates that the prevailing wind directions during KEOPS-2 were 

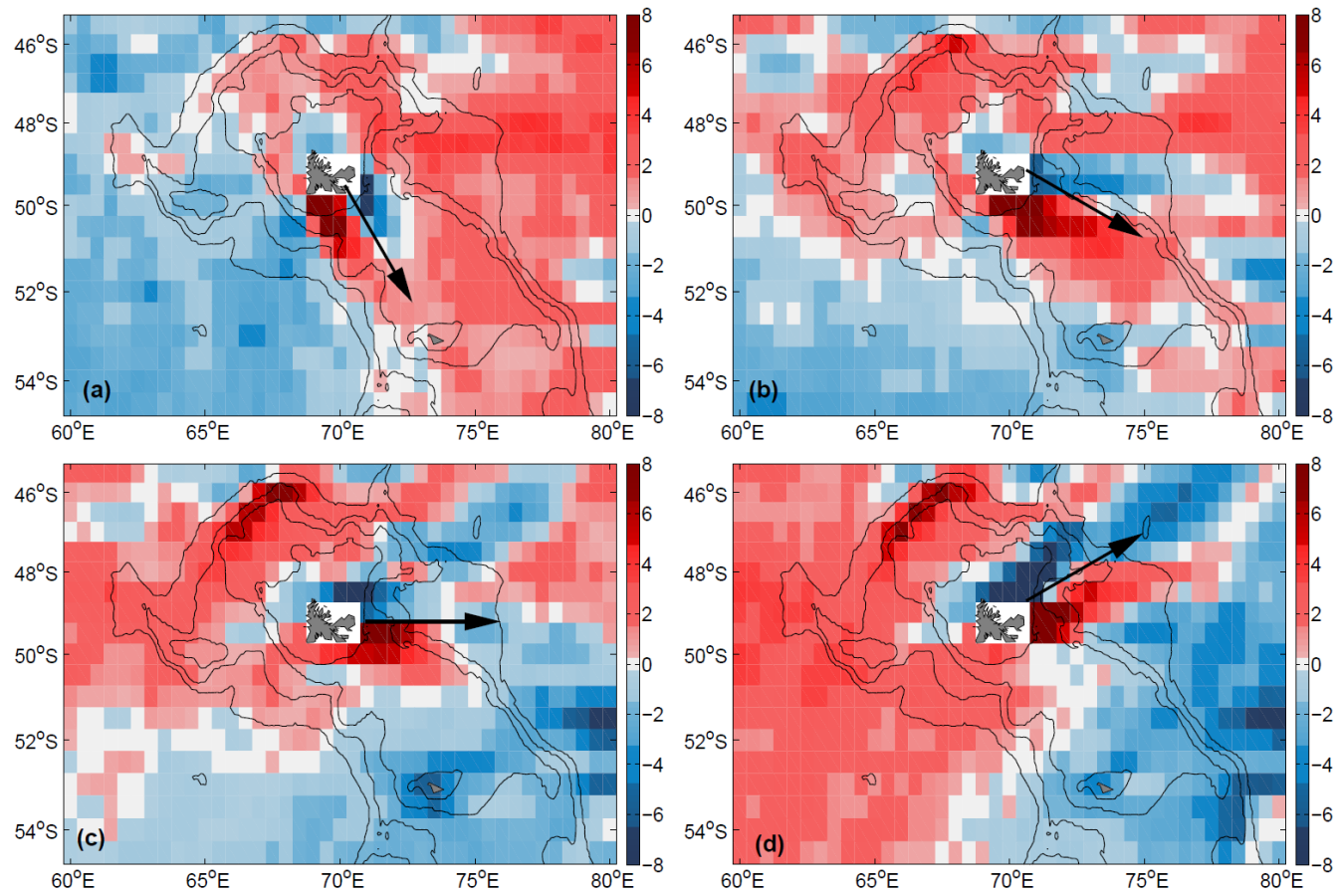

Figure 5. Wind-stress curl (in $10^{-7} \mathrm{~N} \mathrm{~m}^{-3}$ ), sorted by prevailing wind direction for winds (a) from $-75^{\circ}$ to $-45^{\circ}$, (b) from $-45^{\circ}$ to $-15^{\circ}$, (c) $-15^{\circ}$ to $+15^{\circ}$, and (d) $+15^{\circ}$ to $+45^{\circ}$. Contours indicate the $200,1000,2000$, and $3000 \mathrm{~m}$ isobaths. Black arrows indicate the prevailing wind direction for each panel. The maps use Mercator projection so that angles on the map correspond to geographic angles.
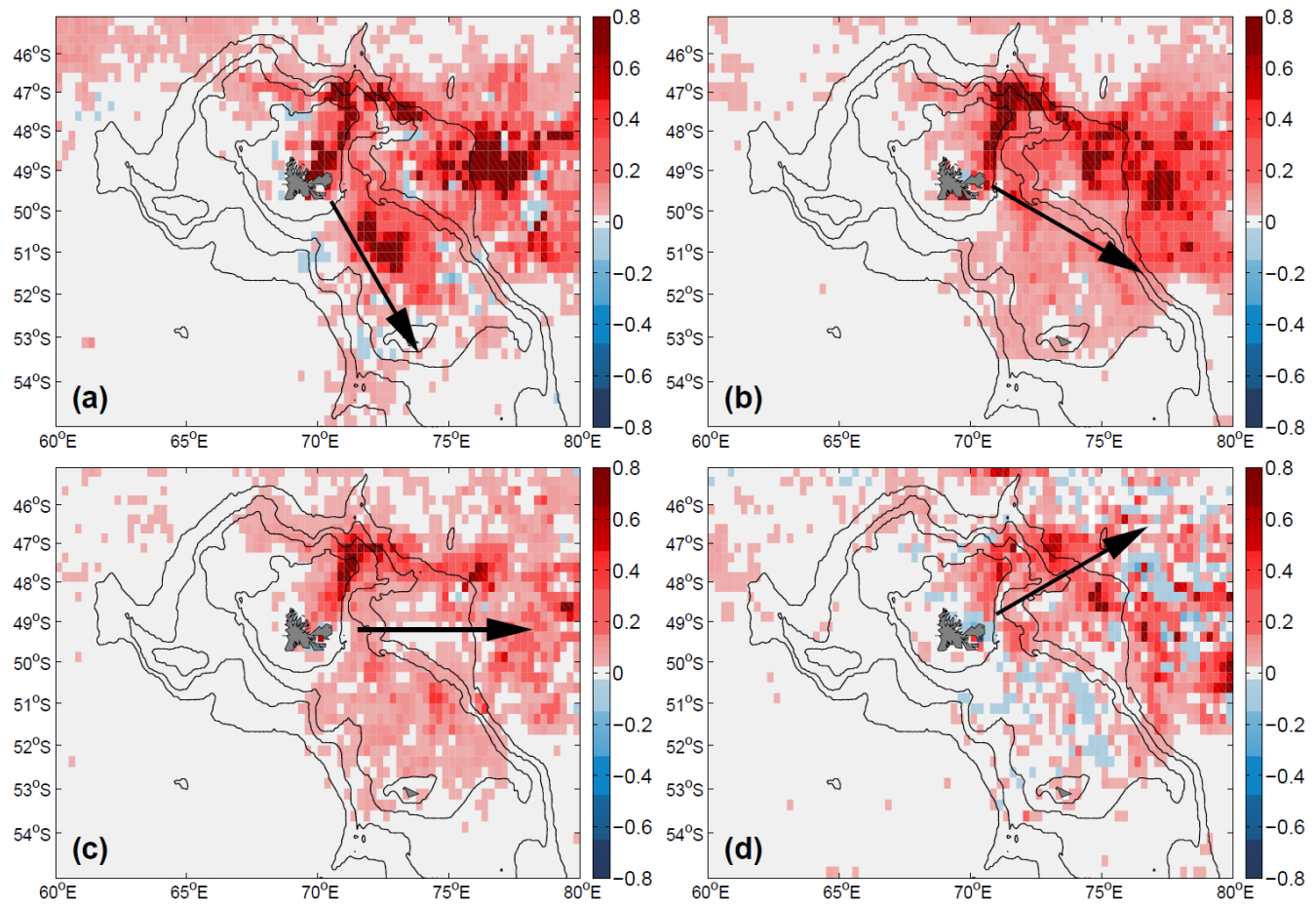

Figure 6. Chl $a$ anomalies in $\mathrm{mg} \mathrm{m}^{-3}$ for the spring-summer growth season (from September through February), sorted as in Fig. 5 by prevailing wind direction for winds (a) from $-75^{\circ}$ to $-45^{\circ}$, (b) from $-45^{\circ}$ to $-15^{\circ}$, (c) $-15^{\circ}$ to $+15^{\circ}$, and (d) $+15^{\circ}$ to $+45^{\circ}$. Fields are computed based on daily data, and $\mathrm{Chl} a$ anomalies are computed relative to climatological monthly means. 

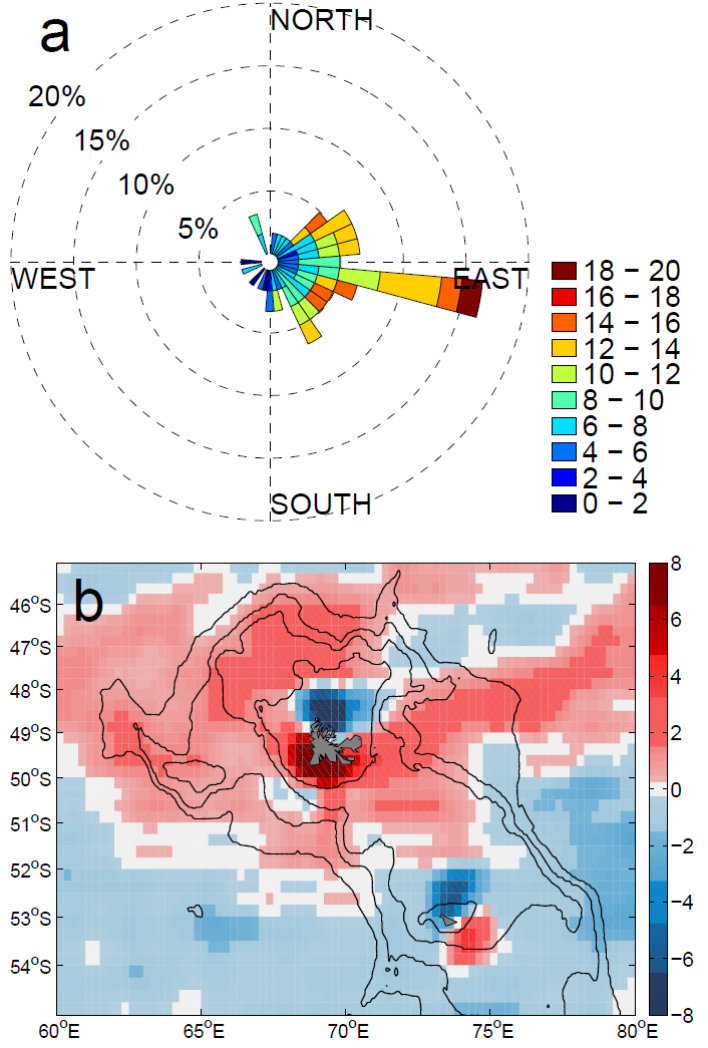

Figure 7. (a) Rose histogram for daily wind direction and speed (colors; in $\mathrm{ms}^{-1}$ ) in October and November 2011, during the KEOPS-2 expedition. (b) Wind-stress curl (in $10^{-7} \mathrm{~N} \mathrm{~m}^{-3}$ ) in October and November 2011. Winds are derived from the CCMP product.

consistent with prevailing wind directions shown in Fig. 4 for the 2002-2009 time period. In 2011, the largest daily average winds were oriented in the direction of most prevalent winds. The time-mean wind-stress curl for October and November, 2011 (Fig. 7b), is consistent with historical trends and indicates negative wind-stress curl, and thus upwelling-favorable conditions, over the shallow plateau to the northeast of Kerguelen. For the KEOPS-2 time period, upwelling-favorable conditions are slightly to the west of the maximum $\mathrm{Chl} a$ (Fig. 1c), suggesting that iron or macronutrients might be upwelled and then advected eastward by the prevailing winds or currents as the bloom develops.

\section{Summary and Discussion}

This study has examined the mechanisms by which wind forcing can influence SST, and by extension iron and macronutrient availability, in the region around Kerguelen, where the KEOPS-2 field campaign was carried out. Although SST and satellite wind data are more limited in October and November, 2011, than they have been in earlier years, Chl $a$ distributions in 2011 (Fig. 1c) are typical of cli- matological Chl $a$ distributions in the region, suggesting that KEOPS-2 is a fairly typical year.

The findings of this study show that the ocean response to wind in the Kerguelen region is characteristic of the largescale Southern Ocean. High wind speeds correlate with cold SSTs (when controlled for air-sea fluxes using the method of partial correlation), implying that wind mixing of the upper ocean entrains cold water into the mixed layer and the euphotic zone, bringing with it iron or macronutrients. In typical spring and summer conditions, this is expected to support the development of a $\mathrm{Chl} a$ bloom. On the large scale, negative wind-stress curl also correlates with cold SSTs, implying that upward Ekman pumping helps bring cold, ironrich water to the surface. Air-sea feedback on the mesoscale modifies these relationships, so that, in most of the region around Kerguelen, we see evidence of a coupling between wind-stress curl and SST gradients, as O'Neill et al. (2003) described.

Exceptions to the expected relationships between windstress curl and SST gradients occur just to the east of Kerguelen, where the wind-stress curl is strongly influenced by the orographic wind shadow of Kerguelen's $1852 \mathrm{~m}$ summit. Persistent negative wind-stress curl just to the northeast of Kerguelen is expected to enhance upward Ekman pumping. Results show that the region of enhanced Ekman pumping coincides with the peak Chl $a$ to the east of Kerguelen.

The magnitude of this wind-induced upwelling remains weak, with a wind-stress curl of 2 to $5 \times 10^{-7} \mathrm{~N} \mathrm{~m}^{-3}$, implying vertical Ekman pumping velocities $(w)$ around $2-4 \times 10^{-6} \mathrm{~m} \mathrm{~s}^{-1}$, giving a change in the thermocline of only 4-11 month $^{-1}$, which is too slow to bring iron-enriched water to the surface, either from the shallow $200 \mathrm{~m}$ plateau or from the sub-surface iron maximum that occurs near a depth of $500 \mathrm{~m}$ (Blain et al., 2008; van der Merwe et al., 2014). However, this could help bring water to the surface from the base of the spring or summer mixed layer or could help to retain water high in Chl $a$ at the ocean surface. Individual storm events could permit stronger short-duration upwelling events. The specific mechanisms governing this will require further investigation.

We note that the satellite-based wind fields have stronger amplitudes and variance than the global meteorological products (e.g., NCEP or ECMWF reanalysis winds). Even so, the gridded wind products we use may still be too smooth and may underestimate the effective wind-stress curl forcing in the region. In addition, we expect larger upwelling and downwelling rates to be induced by the slope current's interaction with bathymetry, or within submesoscale filaments generated by the turbulent flow.

The geographic co-location of the wind-induced upwelling in the Kerguelen wind shadow and the Chl $a$ blooms suggests that, although wind effects are comparatively weak, the wind is able to precondition the background stratification by supporting a shallower thermocline or more upwelling within the mixed layer, allowing other processes to act more 
easily, both to bring iron and macronutrients to the euphotic zone and also to retain $\mathrm{Chl} a$ near the surface. Both horizontal advection (van Beek et al., 2008; Park et al., 2014a; Zhou et al., 2014; Sanial et al., 2014; van der Merwe et al., 2014) and turbulent diapycnal mixing (e.g., Park et al., 2008a, 2014b) are also expected to play key roles in controlling iron and macronutrient availability and biological productivity in the euphotic zone. While many factors contribute to temperature, iron, and macronutrient upwelling in the Southern Ocean, the results of this study suggest that wind-induced properties should be assumed to be a contributing factor in the Kerguelen region, and that the orographically modified wind-stress curl has the potential to be an important factor in explaining the location of the strong $\mathrm{Chl} a$ bloom to the east of Kerguelen.

Acknowledgements. This study has benefited from informal discussions with numerous KEOPS-2 investigators and from helpful suggestions from the anonymous reviewers and Tom Trull. Wind data were obtained from the Centre de Recherche et d'Exploitation Satellitaire (CERSAT), at IFREMER, Plouzané (France). Microwave OI (optimally interpolated) SST data are produced by remote sensing systems and sponsored by the National Oceanographic Partnership Program (NOPP), the NASA Earth Science Physical Oceanography Program, and the NASA MEaSUREs DISCOVER Project. Data are available at www.remss.com. NASA's Research, Education, and Applications Solution Network (REASoN) and MEaSURES programs funded development of the CCMP wind fields, which are distributed by the Physical Oceanography Distributed Active Archive Center (http://podaac.jpl.nasa.gov/). The altimeter products were produced by SSALTO/DUACS and distributed by AVISO with support from CNES (www.aviso.oceanobs.com). Chl $a$ data are processed and distributed by the ACRI-ST GlobColour service, supported by the EU FP7 MyOcean and ESA GlobColour projects, using ESA ENVISAT MERIS data, NASA MODIS, and SeaWiFS data. We gratefully acknowledge support from a NASA graduate student fellowship (MC), from NSF grant nos. ANT-0948338 and OCE1234473 (MC and STG), from NASA grant nos. NNX08AI82G and NNX13AE44G (MC and STG), from the Observatoire MidiPyrénées (STG, RC and RM), and the CNES TOSCA program (RC and RM).

Edited by: T. Trull

\section{References}

Arrigo, K. R., Van Dijken, G. L., and Bushinsky, S.: Primary production in the Southern Ocean, 1997-2006, J. Geophys. Res., 113, C08004, doi:10.1029/2007JC004551, 2008.

Atlas, R., Ardizzone, J., and Hoffman, R. N.: Application of satellite surface wind data to ocean wind analysis, Proc. SPIE, 70870B, doi:10.1117/12.795371, 2008.

Atlas, R., Hoffman, R. N., Ardizzone, J., Leidner, S. M., and Jusem, J. C.: Development of a new cross-calibrated, multi-platform (CCMP) ocean surface wind product, AMS 13th Conference on
Integrated Observing and Assimilation Systems for Atmosphere, Oceans, and Land Surface (IOAS-AOLS), 2009.

Baba, K., Shibata, R., and Sibuya, M.: Partial correlation and conditional correlation as measures of conditional independence, Australian N. Zealand J. Statistics, 46, 657-664, 2004.

Blain, S., Quéguiner, B., Armand, L., Belviso, S., Bombled, B., Bopp, L., Bowie, A., Brunet, C., Brussaard, C., Carlotti, F., Christaki, U., Corbière, A., Durand, I., Ebersbach, F., Fuda, J.L., Garcia, N., Gerringa, L., Griffiths, B., Guigue, C., Guillerm, C., Jacquet, S., Jeandel, C., Laan, P., Lefèvre, D., Lo Monaco, C., Malits, A., Mosseri, J., Obernosterer, I., Park, Y.-H., Picheral, M., Pondaven, P., Remenyi, T., Sandroni, V., Sarthou, G., Savoye, N., Scouarnec, L., Souhaut, M., Thuiller, D., Timmermans, K., Trull, T., Uitz, J., van Beek, P., Veldhuis, M., Vincent, D., Viollier, E., Vong, L., and Wagener, T.: Effect of natural iron fertilization on carbon sequestration in the Southern Ocean, Nature, 446, 1070-1074, 2007.

Blain, S., Sarthou, G., and Laan, P.: Distribution of dissolved iron during the natural iron-fertilization experiment KEOPS (Kerguelen Plateau, Southern Ocean), Deep-Sea Res. II, 55, 594-605, 2008.

Boyd, P. W.: Environmental factors controlling phytoplankton processes in the Southern Ocean, J. Phycology, 38, 844-861, 2002.

Bucciarelli, E., Blain, S., and Treguer, P.: Iron and manganese in the wake of the Kerguelen islands (Southern Ocean), Mar. Chem., 73, 21-36, 2001.

Carranza, M. M. and Gille, S. T.: Southern Ocean wind-driven entrainment enhances satellite chlorophyll-a through the summer, J. Geophys. Res.-Oceans, in press, doi:10.1002/2014JC010203, 2014.

Charette, M. A., Gonneea, M. E., Morris, P. J., Statham, P., Fones, G., Planquette, H., Salter, I., and Naveira Garabato, A.: Radium isotopes as tracers of iron sources fueling a Southern Ocean phytoplankton bloom, Deep-Sea Res. II, 54, 1989-1998, 2007.

Chelton, D. B. and Wentz, F. J.: Global high-resolution satellite observations of sea-surface temperature for numerical weather prediction and climate research, Bull. Amer. Meteor. Soc., 86, 1097-1115, 2005.

Chelton, D. B., Schlax, M. G., Freilich, M. H., and Milliff, R. F.: Satellite measurements reveal persistent small-scale features in ocean winds, Science, 303, 978-983, 2004.

Chelton, D. B., Gaube, P., Schlax, M. G., Early, J. J., and Samelson, R. M.: The influence of nonlinear mesoscale eddies on oceanic chlorophyll, Science, 334, 328-332, 2011.

Chever, F., Sarthou, G., Bucciarelli, E., Blain, S., and Bowie, A. R.: An iron budget during the natural iron fertilisation experiment KEOPS (Kerguelen Islands, Southern Ocean), Biogeosciences, 7, 455-468, doi:10.5194/bg-7-455-2010, 2010.

de Baar, H. J. W., Boyd, P. W., Coale, K. H., Landry, M. R., Tsuda, A., Assmy, P., Bakker, D. C. E., Bozec, Y., Barber, R. T., Brzezinski, M. A., Buesseler, K. O., Boyé, M., Croot, P. L., Gervais, F., Gorbunov, M. Y., Harrison, P. J., Hiscock, W. T., Laan, P., Lancelot, C., Law, C. S., Levasseur, M., Marchetti, A., Millero, F. J., Nishioka, J., Nojiri, Y., Oijen, T. v., Riebesell, U., Rijkenberg, M. J. A., Saito, H., Takeda, S., Timmermans, K. R., Veldhuis, M. J. W., Waite, A. M., and Wong, C.-S.: Synthesis of iron fertilization experiments: From the Iron Age in the Age of Enlightenment, J. Geophys. Res., 110, C09S16, doi:10.1029/2004JC002601, 2005. 
Dibarboure, G., Pujol, M.-I., Briol, F., LeTraon, P., Larnical, G., Picot, N., Mertz, F., and Ablain, M.: Jason-2 in DUACS: Updated system description, first tandem results and impact on processing and products, Marine Geodesy, 34, 214-241, 2011.

Ducet, N., Le Traon, P. Y., and Reverdin, G.: Global high resolution mapping of ocean circulation from the combination of TOPEX/POSEIDON and ERS-1/2, J. Geophys. Res., 105, 19477-19498, 2000.

Dulaiova, H., Ardelan, M. V., Henderson, P. B., and Charette, M. A.: Shelf-derived iron inputs drive biological productivity in the southern Drake Passage, Global Biogeochem. Cy., 23, GB4014, doi:10.1029/2008GB003406, 2009.

Fauchereau, N., Tagliabue, A., Bopp, L., and Monteiro, P. M. S.: The response of phytoplankton biomass to transient mixing events in the Southern Ocean, Geophys. Res. Lett., 38, L17601, doi:10.1029/2011GL048498, 2011.

Frants, M., Gille, S. T., Hatta, M., Hiscock, W. T., Kahru, M., Measures, C. I., Mitchell, B. G., and Zhou, M.: Analysis of horizontal and vertical processes contributing to natural iron supply in the mixed layer in southern Drake Passage, Deep-Sea Res. II, 90, 68-76, 2013.

Freilich, M. H., Long, D. G., and Spencer, M. W.: SeaWinds: A scanning scatterometer for ADEOS II-Science overview, in: Proc. Int. Geoscience and Remote Sensing Symp., 960-963, IEEE, Pasadena, CA, 1994.

Gaube, P., Chelton, D. B., Strutton, P. G., and Behrenfeld, M. J.: Satellite observations of chlorophyll, phytoplankton biomass, and Ekman pumping in nonlinear mesoscale eddies, J. Geophys. Res.-Oceans, 118, 6349-6370, 2013.

Holm-Hansen, O., Kahru, M., Hewes, C. D., Kawaguchi, S., Kameda, T., Sushin, V., Krasovski, I., Priddle, J., Korb, R., Hewitt, R. P., and Mitchell, B. G.: Temporal and spatial distribution of chlorophyll $a$ in surface waters of the Scotia Sea as determined by both shipboard measurements and satellite data, DeepSea Res. II, 51, 1323-1331, 2004.

Hopkinson, B. M., Mitchell, B. G., Reynolds, R. A., Wang, H., Selph, K. E., Measures, C. I., Hewes, C. D., Holm-Hansen, O., and Barbeau, K. A.: Iron limitation across chlorophyll gradients in the southern Drake Passage: Phytoplankton responses to iron addition and photosynthetic indicators of iron stress, Limnol. Oceanogr., 52, 2540-2554, 2007.

Kahru, M., Mitchell, B. G., Gille, S. T., Hewes, C. D., and Holm-Hansen, O.: Eddies enhance biological production in the Weddell-Scotia Confluence of the Southern Ocean, Geophys. Res. Lett., 34, L14603, doi:10.1029/2007GL030430, 2007.

Kahru, M., Gille, S. T., Murtugudde, R., Strutton, P. G., ManzanoSarabia, M., Wang, H., and Mitchell, B. G.: Global correlations between winds and ocean chlorophyll, J. Geophys. Res., 115, 12040, doi:10.1029/2010JC006500, 2010.

Korb, R. E., Whitehouse, M. J., Atkinson, A., and Thorpe, S. E.: Magnitude and maintenance of the phytoplankton bloom at South Georgia: a naturally iron-replete environment, Marine Ecol. Prog. Ser., 368, 75-91, 2008.

Le Traon, P.-Y., Nadal, F., and Ducet, N.: An improved mapping method of multisatellite altimeter data, J. Atmos. Oceanic Technol., 15, 522-534, 1998

Lévy, M., Ferrari, R., Franks, P. J. S., Martin, A. P., and Rivière, P.: Bringing physics to life at the submesoscale, Geophys. Res. Lett., 39, L14602, doi:10.1029/2012GL052756, 2012.
Mahadevan, A., D’Asaro, E., Perry, M.-J., and Lee, C.: Eddydriven stratification initiates North Atlantic Spring phytoplankton blooms, Science, 337, 54-58, 2012.

Maritorena, S. and Siegel, D. A.: Consistent merging of satellite ocean color data sets using a bio-optical model, Remote Sens. Environment, 94, 429-440, 2005.

Martin, J., Gordon, R., and Fitzwater, S.: Iron in Antarctic waters, Nature, 345, 156-158, 1990.

Measures, C. I., Hatta, M., and Grand, M. M.: Bioactive trace metal distributions and biogeochemical controls in the Southern Ocean, Oceanography, 25, 122-133, 2012.

Moore, J. K. and Abbott, M. R.: Phytoplankton chlorophyll distributions and primary production in the Southern Ocean, J. Geophys. Res., 105, 28709-28722, 2000.

O’Neill, L. W., Chelton, D. B., and Esbensen, S. K.: Observations of SST-induced perturbations of the wind stress fields over the Southern Ocean on seasonal time-scales, J. Climate, 16, 2340-2354, 2003.

O'Neill, L. W., Chelton, D. B., Esbensen, S. K., and Wentz, F. J.: High-resolution satellite measurements of the atmospheric boundary layer response to SST variations along the Agulhas Return Current, J. Climate, 18, 2706-2723, 2005.

Park, Y.-H., Fuda, J.-L., Durand, I., and Naveira Garabato, A. C.: Internal tides and vertical mixing over the Kerguelen Plateau, Deep-Sea Res. II, 55, 582-593, 2008a

Park, Y.-H., Roquet, F., Durand, I., and Fuda, J.-L.: Large-scale circulation over and around the Northern Kerguelen Plateau, DeepSea Res. II, 55, 566-581, 2008b.

Park, Y.-H., Durand, I., Kestenare, E., Rougier, G., Zhou, M., d'vidio, F., Cotté, C., and Lee, J.-H.: Polar Front around the Kerguelen Islands: An up-to-date determination and associated circulation of surface/subsurface waters, J. Geophys. Res.-Oceans, doi:10.1002/2014JC010061, in press, 2014a.

Park, Y.-H., Lee, J.-H., Durand, I., and Hong, C.-S.: Validation of the Thorpe scale-derived vertical diffusivities against microstructure measurements in the Kerguelen region, Biogeosciences Discuss., 11, 12137-12157, doi:10.5194/bgd-11-12137-2014, 2014.

Phillips, H. E. and Rintoul, S. R.: Eddy variability and energetics from direct current measurements in the Antarctic Circumpolar Current south of Australia, J. Phys. Oceanogr., 30, 3050-3076, 2000.

Planquette, H., Statham, P. J., Fones, G. R., Charette, M. A., Moore, C. M., Salter, I., Nedelec, F. H., Taylor, S. L., French, M., Baker, A. R., Mahowald, N., and Jickells, T. D.: Dissolved iron in the vicinity of the Crozet Islands, Southern Ocean, Deep-Sea Res. II, 54, 1999-2019, 2007.

Pollard, R., Sanders, R., Lucas, M., and Statham, P.: The Crozet Natural Iron Bloom and Export Experiment (CROZEX), DeepSea Res. II, 54, 1905-1914, 2007.

Prokhorov, A. V.: Encyclopedia of Mathematics, chap. Partial correlation coefficient, Springer, edited by: Hazewinkel, M., ISBN 978-1-55608-010-4, 2001.

Saha, S., Moorthi, S., Pan, H.-L., Wu, X., Wang, J., Nadiga, S., Tripp, P., Kistler, R., Woollen, J., Behringer, D., Liu, H., Stokes, D., Grumbine, R., Gayno, G., Wang, J., Hou, Y.-T., Chuang, H.Y., Juang, H.-M. H., Sela, J., Iredell, M., Treadon, R., Kleist, D., Van Delst, P., Keyser, D., Derber, J., Ek, M., Meng, J., Wei, H., Yang, R., Lord, S., Van Den Dool, H., Kumar, A., Wang, W., Long, C., Chelliah, M., Xue, Y., Huang, B., Schemm, J.- 
K., Ebisuzaki, W., Lin, R., Xie, P., Chen, M., Zhou, S., Higgins, W., Zou, C.-Z., Liu, Q., Chen, Y., Han, Y., Cucurull, L., Reynolds, R. W., Rutledge, G., and Goldberg, M.: The NCEP Climate Forecast System Reanalysis, Bull. Amer. Meteor. Soc., 91, 1015-1057, 2010.

Sanial, V., van Beek, P., Lansard, B., Souhaut, M., Kestenare, E., d'Ovidio, F., Zhou, M., and Blain, S.: Use of Ra isotopes to deduce rapid transfer of sediment-derived inputs off Kerguelen, Biogeosciences Discuss., 11, 14023-14061, doi:10.5194/bgd-1114023-2014, 2014.

van Beek, P., Bourquin, M., Reyss, J.-L., Souhauta, M., Charette, M. A., and Jeandel, C.: Radium isotopes to investigate the water mass pathways on the Kerguelen Plateau (Southern Ocean), Deep-Sea Res. II, 55, 622-637, 2008.

van der Merwe, P., Bowie, A. R., Quéroué, F., Armand, L., Blain, S., Chever, F., Davies, D., Dehairs, F., Planchon, F., Sarthou, G., Townsend, A. T., and Trull, T.: Sourcing the iron in the naturallyfertilised bloom around the Kerguelen Plateau: particulate trace metal dynamics, Biogeosciences Discuss., 11, 13389-13432, doi:10.5194/bgd-11-13389-2014, 2014.
Venables, H. J., Pollard, R. T., and Popova, E. E.: Physical conditions controlling the development of a regular phytoplankton bloom north of the Crozet Plateau, Southern Ocean, Deep-Sea Res. II, 54, 1949-1965, 2007.

Xue, Y., Huang, B., Hu, Z.-Z., Kumar, A., Wen, C., Behringer, D., and Nadiga, S.: An assessment of oceanic variability in the NCEP climate forecast system reanalysis, Clim. Dyn., 37, 2511-2539, 2010.

Zhou, M., Zhu, Y., d'Ovidio, F., Park, Y.-H., Durand, I., Kestenare, E., Sanial, V., Van-Beek, P., Queguiner, B., Carlotti, F., and Blain, S.: Surface currents and upwelling in Kerguelen Plateau regions, Biogeosciences Discuss., 11, 6845-6876, doi:10.5194/bgd-116845-2014, 2014. 